\title{
COMPETITION AND PLURALISM IN PUBLIC BUREAUCRACIES
}

\section{Mick Moore}

\section{INTRODUCTION}

The discipline of public administration has in recent years begun to find itself hosting fundamental theoretical debate and conflict. This is new. The subject has traditionally been relatively technical, vocational and prescriptive: devoted to the refinement and transmission of generally-agreed norms, rules and guidelines about how good administration should be undertaken. This theoretical controversy still has a long way to go; there is widespread disagreement even over the question of what should be the major issues up for debate. I pose them in the following terms:

1 It is helpful to see conventional ('Weberian') approaches to public administration as premised on notion of hierarchical control as the central organizing principle.

2 Two major schools of thought have emerged recently to challenge the Weberian model. One school builds upon solidarity - the informal social links and moral attachments which constitute so much of the meaning of organizational life to its participants - to develop the notion that organizations will perform well because, and insofar as, they also constitute communities. The other school of thought starts from the assumption that behaviour within organizations, far from being shaped by declared organizational goals and norms of procedure, is determined primarily by the perceived self-interest of individual bureaucratic agents.

3 These theorists who assert the primacy of individually self-interested behaviour in shaping the performance of public bureaucracies are, predictably, proponents of material incentives, markets and competition as efficient and desirable mechanisms for the coordination of social life. They may be described as neo-liberals.

4 Neo-liberals differ among themselves in the conclusions for the organization of the public sector that they draw from their assertion of the dominance of individual self-interest motivations. Some have been concerned essentially to disparage public institutions, with a view to justifying as much privatization as possible. However, neo-liberals in power - for which Britain provides the paradigm example - have found privatization to be an incomplete solution. For a range of reasons, they seek both to preserve a substantial state apparatus and to reform it thoroughly. Considerable efforts have been made to find ways of bringing material incentives, markets and competition to bear on the public service.

5 There are, however, a variety of approaches to achieving this general objective. Substantial elements of incentive and market have been introduced. The analogue of market competition - overt competition between public sector agencies (or between public and private sector agencies) for resources and contracts on the basis of past and potential performance - has however found relatively little favour so far. In the first place, it remains largely confined to peripheral activities: competitive tendering out of local government services and of support services to central government activities. In the second place, the type of competition introduced is structurally limited. Implementing agencies are required to compete with one another for funds and contracts from central financing agencies ('unilateral competition'). However, there is no structured competitive process between alternative funding agencies ('bilateral competition'). Competition of such limited scope may not encourage innovation.

6 The scope for improving public service performance by introducing elements of structured competition for resources between different categories of agencies has not yet been fully or consistently explored, even by neo-liberals. Starting from observations and practical experiences of integrated rural development projects in Sri Lanka, I argue the case for experimenting with the introduction of elements of 'bilateral competition' in the organization and funding of some core development activities. My argument is not that the entire government apparatus should be organized for (bilateral) competition, but that there are niches (of unknown size) where such a structure would prove both feasible and effective at providing better and more innovative development services.

The material on Sri Lanka comes towards the end of the article. I approach it by tracing how public administration theorists of different schools have dealt with (or ignored) the fact that incentives, markets and competition can stimulate performance. Before that, I briefly explain the intellectual framework which permits me to categorize different approaches to public administration into three major schools. 
Figure 1: Three Models of Social Coordination

\begin{tabular}{|c|c|c|c|}
\hline $\begin{array}{l}\text { Societal-level } \\
\text { mechanism }\end{array}$ & $\begin{array}{l}\text { Hierarchical } \\
\text { control }\end{array}$ & $\begin{array}{l}\text { Dispersed } \\
\text { competition }\end{array}$ & Solidarity \\
\hline $\begin{array}{l}\text { Principle } \\
\text { motivating micro-level } \\
\text { interactions }\end{array}$ & Duty & Self-interest & Affectivity \\
\hline $\begin{array}{l}\text { Principle regulating } \\
\text { micro-level } \\
\text { interactions }\end{array}$ & Authority & Contract & Mutuality \\
\hline $\begin{array}{l}\text { Associated } \\
\text { institution }\end{array}$ & Organization $^{2}$ & $\begin{array}{l}\text { Market (or democratic } \\
\text { election) }\end{array}$ & Community \\
\hline $\begin{array}{l}\text { Associated mechanism } \\
\text { for staff control } \\
\text { within the } \\
\text { organization }^{3}\end{array}$ & $\begin{array}{l}\text { Feedback control } \\
\text { (close supervision) }\end{array}$ & $\begin{array}{l}\text { Material incentive } \\
\text { control (payment by } \\
\text { results) }\end{array}$ & $\begin{array}{l}\text { Pre-programmed } \\
\text { control } \\
\text { (socialization) }\end{array}$ \\
\hline $\begin{array}{l}\text { Associated mechanism } \\
\text { for state to shape } \\
\text { society }\end{array}$ & Authority & Market & Persuasion \\
\hline Major exponents & Weber & $\begin{array}{l}\text { Niskanen, Tullock - } \\
\text { neo-liberals }\end{array}$ & $\begin{array}{l}\text { 'Learn from Japan' } \\
\text { and 'Better Red than } \\
\text { Expert' }\end{array}$ \\
\hline $\begin{array}{l}\text { Programme for } \\
\text { public bureaucracy }\end{array}$ & $\begin{array}{l}\text { 'Traditional' } \\
\text { bureaucracy }\end{array}$ & $\begin{array}{l}\text { New Public } \\
\text { Management }\end{array}$ & $\begin{array}{l}\text { 'Organization as } \\
\text { community }\end{array}$ \\
\hline \multicolumn{4}{|c|}{$\begin{array}{l}\text { Notes: } \\
\text { 'The table is based on adaptations from a number of sources, notably Ouchi (1980), Str } \\
\text { Thompson et al. (1991) } \\
2 \text { 'Organization' denotes formal organization, not simply stable patterns of transactions } \\
{ }^{3} \text { See Heginbotham } 1975 \\
{ }^{4} \text { See Lindbolm } 1977\end{array}$} \\
\hline
\end{tabular}

\section{MODELS OF SOCIAL COORDINATION}

There is a wide measure of agreement among social theorists, albeit implicit rather than explicit and often expressed through different sets of concepts and jargon, that we can usefully define three main mechanisms, principles or models for the coordination of social life: 'organization' (hierarchy-dutyauthority); 'market' (competition-self-interestcontract); and 'community' (solidarity-affectivitymutuality). These principles operate (or, can be applied) at various levels, including the intraorganizational level. Figure 1 constitutes my preferred way of assembling and labelling the elements of this widely - if loosely - shared conceptual framework. It also provides some illustrations of the applicability of the framework to the analysis of organizational issues. The main purpose is to elucidate the background to my assertion that one can categorize different theoretical and normative approaches to large scale organization into three major schools, each associated with one of these three mechanisms, principles or models. ${ }^{2}$

\footnotetext{
${ }^{2}$ It is implicit in my wording that there is more agreement among theorists about what the main categories are than about what they are categories of!
} 


\section{THE RATIONAL BUREAUCRATIC MACHINE}

There is a powerful conventional model of public administration, constituted at the level of general principles rather than of specific applications, which is premised on the primacy of the mechanisms associated with 'organization': hierarchy, duty and authority. This model goes under many different names, including the 'rational model', the 'Weberian model', and the 'mechanistic-instrumental' or 'machine model'. Even if one avoids naming the model after Max Weber, there is no avoiding the central role of his writings in shaping it. He is not simply the most prominent theorist of bureaucracy, organization and public administration; he is the only theorist to have produced a coherent normative vision of public organization backed up by an impressive corpus of erudite writing. One may talk of 'Weber's model' without attempting to disentangle its analytic, descriptive and prescriptive components.

Weber explicitly used mechanical imagery to characterize modern bureaucracy:

'The decisive reason for the advance of bureaucratic organization has always been its purely technical superiority over every other form. A fully developed bureaucratic apparatus stands to these other forms in much the same relation as a machine does to non-mechanical means of production. Precision, despatch, clarity, familiarity with the documents, continuity, discretion, uniformity, rigid subordination, savings in friction and in material and personal costs - all these things are raised much more effectively to the optimal level by a strongly bureaucratic, especially monocratic, administration with trained individual officials than by any form of collegiate, honorific or avocational administration'

(Weber 1922: 350)

Weber was more aware of the limits and dysfunctions of modern bureaucracy than such quotations imply. ${ }^{3}$ However he had little to say about these limitations, because his focus was on the advantages of bureaucracy over preceding forms of state organization. His work has been used almost consistently in support of the idea of the organizational superiority of the 'bureaucratic machine'. 'Machine' is the appropriate imagery. The analogies between real machines and the Weberian image of bureaucracy are close: the notion of breaking down operations into large number of small, discrete and repetitive tasks ('standardization'); the replicability of the machines themselves in any environment ('insulation of bureaucrats from society'); the complete standardization of components, such that any one be

\footnotetext{
${ }^{3}$ For example, the paragraph following the one quoted in the text ends with the following sentence, in brackets: "It is irrelevant in this context that the bureaucratic machine may, and in fact does, also in its turn create definite obstacles to the possibility of carrying out its task in a manner adapted to the individual case)'. See also Bendix 1966: 427 .

${ }^{4}$ For illuminating discussions of this problem in relation to agricultural extension in developing countries, see Heginbotham
}

replaced only by another which is identical ('impersonality'); the total responsiveness of any component to the component immediately adjacent and above it in mechanical line-of-command ('hierarchy'), leading to the idea of 'instrumentality' that the whole machine can be commanded from the top: instructions from the top will be transmitted to lower levels with little distortion or loss. The machine is not auto-responsive; it has to be directed externally, by the political authority of the state. A useful summary image of the Weberian bureaucracy is the motor car: the car (state machine) is an instrument which will respond to whichever driver (government, in the narrow sense) is currently at the controls.

That modern bureaucracies generally function very differently from the 'Weberian image' is news neither to participants in organizations nor to those familiar with the vast research output of the organization theorists. In many cases, and especially in many developing countries, the most evident reason is that the kinds of assumptions that Weber made about the political environment for effective bureaucratic performance are not met. Bureaucrats are not selected, promoted or rewarded on competence criteria; politicians become deeply involved in matters properly 'internal' to the bureaucracy; and bureaucrats face such personal and career insecurity that they sometimes adopt highly formalistic (and inefficient) procedures to protect themselves against possible allegations of wrongdoing or even of responsibility for particular events or outcomes. The more important point for present purposes is that a great deal of research demonstrates that, even in propitious conditions, a) public bureaucracies of ten do not function according to monistic, Weberian principles; and b) more importantly, those principles may be inimical to effective organizational performance. No organization can be made to function effectively simply through the refinement of the hierarchical model. The list below is not comprehensive. It is intended simply to indicate some of the more significant issues:

1 The Weberian notion of the direct command and oversight of the work of subordinates by superiors is best suited to an office situation in the literal sense of the term. Where subordinates work at a great physical distance from superiors and/or where work 'output' is relatively intangible or otherwise difficult to measure independently, alternative modes of ensuring the compliance of subordinates with organizational goals are required. ${ }^{4}$

\footnotetext{
(1975) and Leonard (1977). More generally, this problem underlies one of the central concepts - 'specificity' - developed by Israel (1987) in one of the more innovative recent books on 'development administration'. The argument, to simplify, is that organizational performance will be better to the extent that tasks are 'specific', i.e. to the extent that failure to perform them (adequately) will be brought to the notice of superiors in some quasi-automatic fashion and that blame can be attached to particular individuals, groups or agencies.
} 
2 No organization can function solely on the basis of formally specified roles and tasks. A great deal of what happens in any organizational environment is unforeseeable; even if foreseen, the number and variety of contingencies is so large that to specify roles and tasks for each would be impossible. Even strict adherence to the existing procedural rules is enough to bring many large public sector organizations almost to a halt - hence the 'work to rule' as the alternative to strike action. Large organizations cannot function without a) routinely ignoring formal procedures and $b$ ) more importantly, depending on a wide variety of informal relationships and transactions between staff members for the transfer of information and resolution of problems. Such informal relations characteristically have a 'horizontal bias', compensating for the 'verticality' of formal procedures and relationships.

3 The hierarchical line-of-command principle which constitutes the core of Weber's model is most effective within individual agencies. It is far less effective as a means of coordinating the relationships between agencies, even in cases where their heads stand in a hierarchical relationship to one another. Subordinate agencies have many resources with which to resist simple hierarchy, including exclusive control of information relating to their own domain and purely nominal compliance. Inter-agency relations are thus complex, and marked by strategic behaviour and bargaining. Inter-agency relations play a major role in the functioning of complex modern state systems.

4 The simple mechanical imagery which so fascinated Weber and many other nineteenth century social theorists is misleading. Few complex systems, whether in the fields of engineering, biology, language, or human organization, operate according to the Weberian image of the finely tuned machine, with each agency or office precisely oriented to a particular function without duplication or overlap. Rather, redundancy - the provision of duplicate elements in any system which will not normally be called into operation, but are available when problems occur - is a central and indispensable element of virtually all complex systems. Aircraft rarely crash because they have a great deal of inbuilt redundancy - back-up components that come into play only when others fail. Because of the high degree of miscommunication which attends all but the most elementary use of language, it (language) is riddled with redundancy. So too are politics, governments, public bureaucracies and processes of market competition (Landau 1969).
5 At the senior-most bureaucratic levels in particular, the Weberian principles of direct, hierarchical supervision of work performance have limited relevance, and, for the 'bureaucratic machine' to be effective, need to be replaced by alternative mechanisms for eliciting good work performance. The most important general reason for this is that the nature of work at these levels tends to be highly diverse, unpredictable and intangible, and therefore not amenable either to close direction or narrow performance evaluation on 'objective' criteria. It has a substantial, direct political content, including policy advice and close liaison with politicians. Like the work of politicians, it often requires rapid response to immediate opportunities and exigencies.

6 The Weberian machine is best suited to perform functions that are both routine and predictable. It is less adapted to dealing with the unpredictable. This is a matter of special concern to those who perceive that dealing with the unpredictable absorbs a great deal of the energies of governments and bureaucracies, and that administrative systems accordingly need to be robust and flexible as well as efficient in input-output terms and fair and reasonable in their dealings with citizens (Hood 1991: 11). Equally, the Weberian machine is not well suited to situations that require creativity and the capacity to learn from experience and mistakes. This limitation is of special concern to those who see the state as an agency for the promotion of economic and social development.

7 It is frequently argued that, due to a) changing social expectations about the nature of work and authority relations, and b) the growing proportion of jobs which require the exercise of intelligence ('knowledge work'), the direct, hierarchic control of job content and performance implicit in the Weberian model is increasingly becoming an obstacle to work commitment, creativity and effective job performance generally. Direct and close supervision of job performance generates negative reactions and a sense of alienation on the part of subordinates, and may anyway be very costly. (The strength of this argument depends upon the social context and on the nature of the job.)

The persistence of the Weberian ideal in the face of so much contrary evidence must be due at least in part to political factors: to the fact that the image of bureaucracy which it conveys is comforting and convenient to many of the parties concerned. ${ }^{5}$ Why however did Weber himself did not foresee the limitations and contradictions of the machine model, and explore the possibilities of using supplementary mechanisms to guard against bureaucratic pathologies?

(b) of a clear dichotomy between politicians who make policy and public servants who merely implement it clearly have great appeal to taxpayers and to politicians as well as to bureaucrats.

\footnotetext{
s Public servants play a major role in researching and teaching about public administration, and are thus well placed to replicate the images and doctrines with which they are most comfortable. The Weberian notions of (a) bureaucracy as an efficient machine, and
} 
Answers to these questions depend essentially on interpretations of Weber's silences. One potential answer has already been suggested above: Weber was much more interested in the superiority of contemporary bureaucracy over pre-modern state forms than he was in the dysfunctions of modern bureaucracy. Another is that he had such a profound faith in the devotion to the state of the (Prussian) 'service class' that he did not appear to have seen their motivation as particularly problematic. ${ }^{6}$ Whatever the reason, Weber implies that the mechanisms of meritocratic staff selection and promotion, discipline and internal hierarchy were adequate to combat the temptations to self-interested behaviour inherent in the way in which formal organization insulates individual bureaucrats from the consequences of many of their actions.

Weber's image of organizational life is simplistic. Contemporary researchers have found the situation to be so different - so intrinsically complex - that some have suggested that the functioning of public bureaucracies cannot be understood through any kind of instrumental or consequential model which assumes some consistent relationship between the intentions of participants and final outcomes. The talk is instead of 'temporal sorting' or 'garbage can' models. The fundamental idea behind these images is that organizational participants are so pressurized by endless complex demands and shortage of time that the best they can do is to cope; in the process, any 'project' - an intention to use a particular channel or device to achieve some goal - may melt away or lead to a very different outcome from the one intended:

'In temporal sorting models the (decision-making) process depends on a complicated mosaic of attention that makes the particular pattern of linkages among problems, solutions, and choice seem quite chaotic from a means-ends point of view'

(March and Olsen 1989: 14)

Temporal sorting models can however be wholeheartedly embraced only by sceptics who see little prospect of using public bureaucracy in an instrumental fashion. Those who retain some faith in the possibilities of intentional public action plump for theories of bureaucracy and organization with a higher prescriptive content. Two such theories or schools of thought, both consciously non-Weberian, have become prominen: in the last couple of decades. The first is sometimes labelled the 'human relations' school; I prefer the term 'organization-as-community'.

\footnotetext{
${ }^{6}$ So eulogistic is much of Weber's characterization of bureaucracy that I have some sympathy with the following ferocious attack by the economic liberal, Ludwig von Mises, on Weber and his ilk:

'It was a purposeful confusion on the part of the German metaphysicians of statolatry [worship of the state $-M P M$ ] that they
}

\section{NON-WEBERIAN THEORIES - 'ORGANIZATION-AS-COMMUNITY'}

The central idea of the 'organization-as-community' school is the transformation of the organization (articulated by hierarchic command-obedience relationships) into a community, where relationships of solidarity and mutuality predominate. This, it is argued, will make it more effective. The following quotation conveys the flavour of this school of thought:

'One sign of the new sorts of organization is a perceptible change in the language we use to talk about them. Organizations used to be perceived as gigantic pieces of engineering, with largely interchangeable human parts. We talked of their structures and their systems, of inputs and outputs, of control devices and of managing them, as if the whole was one large factory. Today the language is not that of engineering but of politics, with talks of cultures and networks, of teams and coalitions, of influence or power rather than control, of leadership not management. It is as if we had suddenly woken up to the fact that organizations were made up of people, after all, not just 'hands' or 'role occupants'

(Handy 1990: 71)

The ideas of the organization-as-community school are founded upon the concerns mentioned in Section 3 about the adverse effects on work performance of the kinds of workplace human relations implicit in Weberian bureaucracy. More precisely, there appear to be three central propositions, from which a wide range of others can be derived:

1 Direct and close supervision of work - and especially of how work is done, as opposed to the quantity and quality of output - is both directly inefficient because of the high supervision costs involved, and indirectly costly because this tends to discourage creativity and to demotivate workers, especially 'knowledge workers'.

2 More generally, workers will perform better if they have a sense of commitment to the employing organization and an understanding of its goals. (There is a great deal of concern with 'leadership' and the transformation of the organization into a moral community.)

3 Creativity and flexibility are becoming increasingly important requirements for organizations in a world characterized by increasing market competition and

clothed all men in the government service with the gloriole of altruistic self-sacrifice. From the writings of the German etatists the civil servant emerges as a saintly being, a sort of monk who forsook all earthly pleasures and all personal happiness in order to serve, to the best of his abilities' (1944: 78). 
accelerating rates of technical innovation. It is the identification of workers with the organization, rather than the Weberian identification of individual workers with particular defined roles and tasks, which is most likely to elicit this creativity and flexibility.

In Search of Excellence by Peters and Waterman (1982) has been the most influential text of the organizationas-community school. The book conveniently encapsulates the dominant characteristics and limitations of the school generally. Six points are of special interest here:

1 The tone is dominantly prescriptive, designed to persuade managers to turn their companies into communities. There is little concern with the limits of the organization-as-community model or its appropriateness to particular tasks or contexts. One of the fundamental axioms of organization theory - that different types of organization are appropriate to different tasks and environments - is ignored if not explicitly denied. ${ }^{7}$ Equally, there is no recognition of the central strength of Weberian organization and of the dangers of sacrificing this in the rush towards group-focused organization:

Hierarchy . . . is the only form of organization that can enable a company to employ large numbers of people and yet preserve unambiguous accountability (emphasis added - MPM) for the work they do'

(Jacques 1991: 109)

2 The model for emulation is Japanese industry - at least, the core Japanese companies which offer life-time employment and go to considerable lengths to achieve a strong sense of identification with the company on the part of employees.

3 The focus is exclusively on the private sector; there is no concern (in the book) with possible applications in the public sector. ${ }^{8}$

4 Further, the research behind the book was conducted largely in 'high-tech' American companies, especially those involved in informatics, ${ }^{9}$ which was a fast changing sector at the time the book was being

\footnotetext{
${ }^{7}$ The principal author, Peters, took this voluntaristic approach (i.e. a belief in the primacy of human will over structural factors) further in his next best-selling book, Thriving on Chaos (1987), which, as the title indicates, essentially urged managers to renounce any hopes of organizational stability.

${ }^{8}$ This is not to argue that the model has no application to the public sector; indeed, it certainly does. There are important elements of the community model in many successful organizations.

'See the list of companies studied on pp 20-21 of the book.

${ }^{10}$ Proponents of this school are typically very critical of the 'AngloAmerican' management practice of viewing labour simply as a commodity to be hired and fired according to short term needs, and advocate instead 'investment in people'. Indeed, many of the cases of
}

written. This helps explain the obsession with creativity, flexibility and responsiveness to a very rapidly-changing external environment.

5 Relatedly, the model is premised on the assumption that people prefer to work in a relatively unstructured and flexible organizational environment. This may be no more justifiable than the opposite, Weberian assumption that: 'People tend to be most content when they work under conditions of structural simplicity, where relationships are unambiguous, tasks are clearly defined, performance standards are stipulated, and the working environment is free of conflicting pressures' (Esman 1991: 74).

6 High quality management ('leadership') is the strategic variable in this model.

A more extended discussion of the strengths and limitations of the organization-as-community school would be out of place here. Like the other approaches, it contains a great deal of value: effective organizations are those which develop appropriate blends of elements from different schools; all organizations are mixed systems. The organization-as-community school does not solve our problems, and especially not in relation to the public sector. For it essentially assumes a competitive environment, and deals with the problem of how to structure the individual organization (firm) to deal effectively with that environment. ${ }^{10}$ It does not tackle the issue which the neo-liberals see as central to the performance of public institutions: the provision of compelling incentives to efficient performance.

\section{NON-WEBERIAN THEORIES - 'ORGANIZATION-AS-DISGUISED-SELF- INTEREST'}

The intellectual foundations of the neo-liberal approach to public organization are contained in two books; Gordon Tullock (The Politics of Bureaucracy, 1965, republished 1987); and W. A. Niskanen (Bureaucracy and Representative Government, 1971). ${ }^{11}$ They both start from unexceptionable premises: that a great deal of the energy and resources absorbed in formal organizations are directed to the pursuit of the personal goals of the staff rather than to achieving the

dramatic success of the model in the private sector appear due in large part to the enhanced commitment of the labour force to the company which follows the adoption of the policy of avoiding compulsory redundancies during economic recession. Because of their different employment contracts, public agencies rarely have the opportunity to reap such once-off gains. However, even in the private sector, a competitive labour market does constitute one of the underlying conditions for the operation of the organization-as-community model.

${ }^{13}$ For present purposes, the 1973 pamphlet is an adequate introduction to Niskanen's work. For a more detailed introduction to this literature see Jackson 1985: chapter 5. 
organizations' professed objectives and purposes; and that, because of their privileged access to information about their own activities and their great capacity to deploy their own organization in self-defence, bureaucracies typically have considerable capacity to evade public and political scrutiny. Such insights are the stock-in-trade of virtually all critical approaches to the study of public administration (e.g. Schaffer 1980; Wildavsky 1979). The neo-liberals have attempted to go beyond insight and develop predictive models of bureaucratic behaviour on the basis of a few simple assumptions about how individual bureaucratic actors use the organizational context to pursue individual self-interest. There are substantial differences between Tullock and Niskanen which correspond to their underlying political programmes.

Tullock's model of bu reaucracy gives 'special emphasis to the behaviour of an intelligent, ambitious and somewhat unscrupulous man in an organizational hierarchy' (1987: 26). The key steps in his argument are: a) the main goal of bureaucrats is to rise rapidly in the career hierarchy; b) bureaucracies provide great scope for concealment or manipulation of information; c) the people who are promoted most rapidly are those who are most ruthless and successful in manipulating information to provide a favourable picture of their own performance; d) bureaucracies are inherently ineffective and inefficient because the top ranks are filled with unscrupulous and untrustworthy people skilled at manipulation; and e) bureaucracies are therefore unable to fulfill the complex tasks set them.

One need say little more about Tullock's work. He makes no attempt to provide supporting evidence, and indeed suggests that this is not necessary because rightthinking people will instinctively recognize the truth (1987: 14-15). As a contribution to the general disparagement of public bureaucracies, his work may be politically effective. It points to privatization wherever possible; to as much decentralization as possible so that the local community - the authentic socit:tal realm - can exercise maximum influence over the apostate realm of bureaucrats and politicians (1965: chapter 25); and to a minimal public sector; it does not address the question of how the (residual) public service is to be organized.

Niskanen's theory, unlike Tullock's, arose out of very practical concerns: his work as an economist trying to establish mechanisms to control American defence expenditure. It takes as the central problem 'bureaucratic imperialism': the alleged tendency of bureaucratic agencies to continually push to expand in size, scope and responsibilities, and to evade budgetary scrutiny conducted by legislators. Niskanen's 'bureaucracy' comprises an aggregate of 'bureaux', whose defining characteristic is that they are financed from grants or periodic appropriations from public funds rather than from profits. $\mathrm{He}$ is implicitly concerned with bureaux which produce identifiable goods and services, not with 'policymaking' in the broad sense of the term. For analytical purposes Niskanen reduces the general phenomena of bureaucratic imperialism to one of continual pressure from bureaux to expand their own budgets. He assumes that this is the common objective of both the head of each bureau and the staff. Where Tullock reduces complexity by assuming that the only significant actors are individual bureaucrats, Niskanen achieves the same goal by collapsing individuals' motivations and behaviour into that of the bureaux. It is the latter which are the actors in his model.

The novel and most useful feature of Niskanen's work is his analysis of the relationship between the individual bureau and its 'sponsor' - the central government Ministry which secures its funding, takes overall responsibility for its performance, and generally provides the key political linkages to the government. Niskanen analyses this bureau-sponsor relationship in terms of the concept of 'bilateral monopoly'. He argues that in such a relationship each side needs the other. The bureau needs its funds, but the sponsor is also responsible for ensuring that the work for which the bureau has a mandate - whether that be cleaning the streets or inspecting nuclear power stations - is carried out without interruption. Bilateral monopoly leads to tortuous bargaining relationships. ${ }^{12}$ Because individual bureaux have superior access to information and superior, concentrated organizational capacity in relation to their sphere of operations, they can usually outmanoeuvre attempts by their sponsors or other external agents to subject them to thorough scrutiny. The relationship of bilateral monopoly is skewed to the advantage of the bureau..$^{13}$ The main, original, practical implication of Niskanen's work concerns the possible advantages of terminating bilateral monopoly. He advocates structured competition for funds between different bureaux, each tendering openly for resources and therefore exposing themselves to pressures towards economy and efficiency far more effective than administrative or political scrutiny alone.

\footnotetext{
12 'As with all such relations (including conventional marriage), this relation is awkward and personal - characterized by both threats and deference, by both gaming and appeals to a common objective. No other type of relation combines threat, exchange, and integrative relations in such equal proportions' (Niskanen 1973: 14).
}

\footnotetext{
${ }^{13}$ One might note that one can analyse in much the same terms the relationship between regulatory agencies and the organizations they regulate (Pfeffer and Salancik 1978: 210-13).
} 
Conventional model 1 incomplete separation

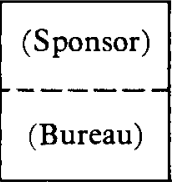

Conventional model 2 -

bilateral monopoly

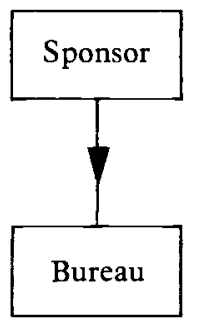

Niskanen's neo-liberal model unilateral competition

Bilateral competition
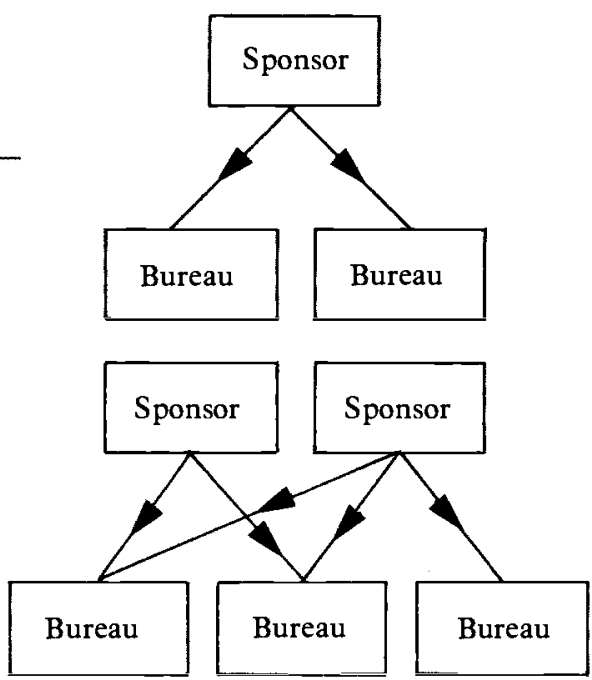

There are three general comments about Niskanen's theory relevant to present concerns:

1 His model of bureaucratic behaviour, like Tullock's, is simplistic. Both ignore the fact that almost all large formal organizations have internal assessment and promotion procedures which are precisely intended to oblige ambitious staff members to earn credit by taking into account the wider goals and ethos of the organization, not just the parochial interests of themselves or their bureau. The complex structure and environment of formal organizations is such as to provide the rational, materially self-interested individual staff member with a wide choice of strategies, some mutually reinforcing and some conflicting according to circumstances: more or less corrupt use of position for immediate gain; cooperating in promoting the interests and expanding the resource base of the bureau to which one is attached; personal loyalty to powerful patrons (or peer groups) inside or outside the organization; or compliance with the criteria for meritocratic promotion. In deductive theorizing about such a complex environment, one can 
largely determine one's conclusions through choice of initial assumptions. Accordingly, a few changes in the assumptions on which these neo-liberal models are based have led to radically different conclusions. ${ }^{14}$

2 Niskanen's perspective and conclusions appear conservative in the light of the radical potential of his premises. This conservatism appears in two dimensions. Firstly, he does not even raise the question of the potential for extending his proposals about interbureau competition for funds from the same sponsor ('unilateral competition') to inter-sponsor competition to support the activities of the same bureaux ('bilateral competition' - see Figure 2). Why should not the various agencies responsible for promoting, say, rural road construction in Sri Lanka be free to compete for and accept funds from both the Ministry of Highways and the Integrated Rural Development Projects? Secondly, and relatedly, in Niskanen's model, interbureau competition for funding is being used solely for cost control and cost cutting purposes. The monopolistic state agency (the sponsor) still defines how particular goals are to be achieved, leaving the bureau simply to implement at least cost. In these two senses, Niskanen is fully representative of the neo-liberal administrations which have derived inspiration from his work - above all, successive British governments since 1979. As an advocate of more radical neo-liberal reform of the British public sector said of the introduction by Margaret Thatchers's government of competitive tendering for service provision:

'All the crucial management decisions would rest in the public sector. It was just that the manager would be driving a better machine. But that is an eviscerated, anodyne, heat-treated form of capitalism. It is capitalism without the best bits the enterprise and the innovation. ${ }^{15}$

Niskanen is implicitly advocating the analogue of what economists terms 'static' (or 'Walrasian', 'neoclassical') competition: competition within the bounds of existing, known technology and methods which is aimed at finding the most efficient agent to do a defined job most cheaply. This is contrasted with 'dynamic' ('Schumpeterian') competition: a process built on the encouragement of innovation in which success comes not to those who can do things the existing way more

\footnotetext{
${ }^{14}$ Niskanen's central proposition is that politicians and legislators are unable to control bureaucrats. Weingast, using alternative but equally simplistic behavioural assumptions, reaches the opposite conclusion (Moe 1984: 769-772). A. J. Downs, celebrated as one of the early exponents of the use of the deductive rational choice method for political analysis, applied it to public bureaucracy (1967). He also comes up with a 'conclusion' unpalatable to the neo-liberals: that levels of public expenditure will be too low in democracies. Neoliberals do not quote his work.

${ }^{15} \mathrm{D}$. Willetts of the Policy Studies Institute in New Society, 14 August 1987: 10. Much the same point is made by Lim and Moore (1989: 154) in their evaluation of the contracting out of infrastructure
}

cheaply than the next firm, but to those who can find radically new ways of doing things.

3 Niskanen's work is analytically useful and has been practically influential, even if only in a relatively diluted form. Even Niskanen's own, relatively conservative programme for obliging implementing agencies to compete with one another for funds and contracts has so far found little favour in Britain outside the sphere of the contracting out of local government services and of support services to central government agencies (office cleaning, infrastructure maintenance, catering) - where competition rarely involves more than a single public bureau, along with private sector rivals. Core government activities - and the centralization of political power - have barely been touched by the neo-liberal agenda. However, the way in which Niskanen addresses the issue of vertical interagency relations appears to have influenced major changes introduced in very recent years in central government institutions in Britain. A clear distinction is being made between a) central institutions (Ministries) concerned with policy making and funding decisions ('sponsors' in Niskanen's terms); and b) semiindependent implementing agencies, whose managers have considerable discretion to contract independently in labour, product and service markets and to make flexible tse of agreed budgets provided they deliver services as contractually agreed ('bureaux' in Niskanen's terms). Evaluations of cost-effectiveness in service provision becomes the major focus of sponsor-bureau relationships. This 'new public management' model, which includes additional elements such as merit payments and more flexible labour contracts within central institutions (Hood 1991), owes a great deal to pragmatic experiment as well as to doctrine. ${ }^{16}$ Niskanen's influence is however evident. So far, the neo-liberal reform of British central government has placed more emphasis on the introduction of elements of (individual) incentive and market than of competition. However, the institutional and procedural recognition of the bargaining relationship between the policymaking/funding role and the implementing role creates conditions under which greater degrees of inter-agency competition could be introduced in the future - and indeed are being introduced at the time of writing.

construction in Honduras: ... the government inspected facilities according to specification codes rather than performance codes. In this context, private companies did not have incentives to introduce new techniques of construction or innovative managerial processes to cut down costs.'

${ }^{16}$ This pragmatism helps explain why the 'new public management' was in most respects developed only slowly, relative at least to the implementation of some other dimensions of the neo-liberal agenda under Margaret Thatcher's Prime Ministership. It is only in very recent years that the 'new public management' agenda can be said to have become a government priority. 


\section{WHAT ABOUT THE DEVELOPING WORLD?}

The applicability to developing countries of ideas of competition and tendering within the public sector and for public services has not yet been seriously explored. There are grounds for caution. For competition and tendering of any kind can only be successful if a) markets in general work relatively effectively (and competitively); and b) the public bureaucracy has the necessary capacity, honesty and motivation to ensure genuine competition and effective regulation in the public interest. ${ }^{17} \mathrm{I}$ have considerable sympathy with the argument that many developing countries face a more urgent task: the (re)creation of a public service which meets minimal 'Weberian' requirements - a degree of autonomy from ruling politicians; standard procedures; prime dependence on official salaries rather than 'unofficial' earnings; recruitmert and promotion on the basis of professional qualifications and competence, etc. At the same time, it was a positive experience in a developing country that initially drew my attention to the possible scope for productive competition within the public bureaucracy - a type of competition in some respects more radical than that advocated by most neo-liberals for developed countries.

\section{SOME FIELD OBSERVATIONS}

During the 1980s I was a frequent consultant on Sri Lanka's Integrated Rural Development Programme (IRDP). This programme took the form that has in other contexts been derided as 'rent-a-district': individual foreign aid donors funded IRD projects in separate administrative districts; special IRDP Project Offices, outside the regular government structure, were established in each beneficiary district, under the coordination of a special agency in Colombo; the officers in charge of these Project Offices were influential figures within the district; there was considerable variation a) in the substance of the IRD projects at district level; $b$ ) in the formal and actual financial and other supervisory relationships between the Project Office and superior authorities - the Regional Development Division of the Ministry of Plan Implementation in Colombo, the Colombo offices of the aid donors, and the donors headquarters overseas; and these differences to a large degree reflected the donors' preferences and practices.

While the programme was not a roaring success - and nothing could have been a great success in a country which was being wracked by a series of armed political conflicts - I observed that the IRD projects were a significant source of practical innovative ideas over a range of rural development policy arenas. I am not referring to brilliant novel ideas, but to the introduction of practical solutions to long-standing problems. Many of these solutions involved the removal of obstacles to 'commonsense' practices through sensible modification of formal bureaucratic rules or procedures and adoption of less formalistic approaches to organizing public action. For example:

1 The inability of government departments to construct low-cost rural feeder roads adequate to provide basic access by wheeled vehicles (tractors, carts) to remote settlements led to the development of a successful system of sub-contracting such tasks through local Rural Development Societies. This replaced an arrangement in which regular government agencies employing engineers had been funded to do the same job. They proved themselves incapable of constructing anything except very expensive carriageways built to unnecessarily high technical specifications, when all that was required was earth-moving, some rock-breaking, and the installation of some pre-cast culverts.

2 The insistence on consulting with resident estate labourers about the modalities of providing improved sanitation and housing facilities led to the evolution of physical designs and implementation schedules which helped to ensure that, unlike in the past, the new facilities were likely to be used and maintained. Without such consultation there had been no recognition of the facts that: common toilet facilities were not cleaned and thus quickly fell into disuse; even miserably-poor estate labourers had definite ideas and preferences about the location of toilets; and the construction of new latrines before the provision of running water was likely to mean that they would not be properly cleaned and would therefore quickly fall into disuse (Laing 1986).

3 IRDP funders learned from their early experiences that conventional afforestation programmes were highly ineffective and therefore not worthy of financial support. This led the Forestry Department to embrace the ideas of: consulting with local villagers about the location and scheduling of planting programmes and the tree species to be cultivated; and employing these villagers in the replanting programme. Villagers then developed some interest in the maintenance and preservation of plantings. They were less likely than before to find that the land they regularly (albeit illegally in a formal sense) used for shifting cultivation had been snatched away. They were more likely to be able to use the new plantations to gather fruits or firewood. The temptations to burn newly-established plantations were thus reduced (IRDP 1987).

Other significant innovations were made in the

${ }^{17}$ For a case study, see Lim and Moore 1989. 
procedures for rehabilitating small scale irrigation reservoirs and obtaining the genuine participation of farmers in water managment; in arranging to procure school furniture from neighbourhood furniture makers rather than through normal commercial channels; and in mobilizing and motivating groups of young people to become effective community development agents.

It seemed clear to me that an important part of the reason for this good record of practical innovation was that the various officials responsible for the IRDP were engaged in processes of competition for resources. They wanted their programmes to do well, and to be seen to do well, because, apart from the intrinsic job satisfaction involved and the scope for winning the approval of high status outsiders, this was the route to obtaining additional resources for their agencies. This competition took a variety of forms at different levels and in different contexts; was generally unstructured; was tacit rather than explicit, and indeed often unrecognized; was generally very much muted and partial; was successful in producing innovation in programme delivery in part because of the diversity of ideas and experiences which came with the variety of foreign aid donors and consultants; and was never intended by any of the main parties involved.

The initial allocation of districts to donors was largely a domestic political decision, and the initial pattern of IRDP expenditures within each district largely reflected local bureaucratic and political interaction. However, once financial disbursement began, donors began to take a more active hand, and bidding processes gradually emerged. The IRDP Project Offices in the districts were not implementing agencies. They worked almost exclusively by channelling funds through the existing district level offices of the established government agencies. These district level offices could see that the allocation of IRDP funds was highly discretionary, and that one could obtain extra money, or enter the programme if not yet part of it, by satisfying the right people about one's actual or potential performance. ${ }^{18}$ IRDP expenditures were generally flexible in practice, and often in principle: substantial reallocations of funds between agencies within a district could be effected on a year-to-year basis. This competition among agencies within the district ${ }^{19}$ was mirrored by competition a) between the district IRDPs for the reputation and image that would encourage their foreign donors to increase budgets ${ }^{20}$ or otherwise show favour; ${ }^{21}$ and $b$ ) among the aid donors themselves. Donors not only tended to view with one another for the reputation of running the best IRDP, but also, as the programme established a good reputation and expanded, they came into increasingly direct competition with one another for 'possession' of the remaining districts not yet allocated to a donor'22 and for the good offices and limited personnel and organizational resources of the agency of the Government of Sri Lanka responsible for the IRDP programme at a central level, the Regional Development Division. This Division had every interest in the IRDP programme being judged a success, for this was its sole significant activity; the Division continuously sought a long term role and resources for itself and the IRD programme.

In discussions over the IRDP, these elements of competition - and the diversity of project content and organizational arrangements on which the processes of competition and innovation were in part founded were either not recognized or, if recognized, considered to be illegitimate but regrettably unavoidable temporary expedients. The long run goals were always taken to be a return to administrative 'normality': IRDPs would eventually conform to a standard pattern of content and procedure; the institutions and personnel running them would be re-absorbed into the 'regular' administration; and the tensions and anomalies believed to stem from the 'irregularities' of the IRDPs would disappear. This to my mind was a clear example of the 'ideological hegemony' exercised by the Weberian model of bureaucracy. Ideas were not pursued - and some facts not even recognized because they did not fit into a particular view of how the world both 'normally' functioned, and how it should function. ${ }^{23}$

\footnotetext{
${ }^{18}$ For some district level line offices of central departments, the IRDPs were virtually the sole source of funds for operational programmes; funding from central sources covered salaries and little else.

${ }^{19}$ IRDP funding and activities sometimes gave rise to tensions between (a) the central offices of government agencies, concerned to assert 'normal procedures' and central control; and (b) the district level officials, who had the greatest interest in participating in the IRDP. There were however cases where local agencies were not very interested in competing for IRDP funds. One reason was probably that adequate funds could be obtained through normal channels without incurring the 'transaction costs' involved in participating in the IRDP - the special procedures, the extra meetings, and the relatively intensive scrutiny of performance by external agents. There were in addition cases where the funding systems of government agencies were so centralized that local offices had no
}

incentive to participate in the IRDP because this did not improve their own resource position. What they gained from IRDP funding would in fact be lost by reduced allocations from other sources.

${ }^{20}$ The proportion of total IRDP costs met by foreign donors varied, but generally equalled or exceeded 70 per cent. This high figure gave the donors a strong bargaining position in relation to the Government of Sri Lanka in negotiations over IRDP funding levels.

${ }^{21}$ Including, for example, by funding officials to go on courses and visits overseas

${ }^{22}$ I recall participating, in the office of one bilateral aid donor, in tidying away copies of a new IRD project proposal from an agency of the Government of Sri Lanka because the local head of another (very fraternal) donor agency was about to arrive. We did not want him to learn of the existence of this proposal and step in first. 


\section{BUREAUCRATIC COMPETITION AND DEVELOPMENT PRACTICE}

In one respect the competitive process observed in Sri Lanka was more limited than that associated with the standard neo-liberal programme of tendering out of service provision: it was even less akin to full market competition. There was no question of public agencies completely losing their funding, and thus being forced into liquidation, through inability to win 'contracts'. In the case of 'core' government agencies, one is talking of competition at the margin for additional resources. However, in two respects the Sri Lankan case represents a more radical approach to public service competition than the usual neo-liberal formula. Firstly, the competitive process was affecting core government activities, and not merely peripheral supporting services. Secondly, the competitive process was bilateral rather than unilateral: funding agencies did not have monopolistic control over implementing agencies, but had to some degree to compete among themselves.

There is insufficient evidence to demonstrate conclusively my assertion that this competitive structure - and especially the existence of bilateral competition - was a prime cause of the innovativeness in the rural development programme. One would need more information on a variety of cases before one could confidently draw lessons. That evidence can only be obtained by recognizing that the argument in principle for an element of structured bureaucratic competition is quite coherent, and that the scope - especially for bilateral competition - has not been explored.

All effective solutions to problems of organizational performance will involve some appropriate mix of very different organizational principles. Bure«ucratic competition is not a panacea for the basic weakresses which affect public administration in many poor ccuntries; it is more a 'niche product' - and the size of the niches has not yet been explored. Let us conclude with a few general propositions about where these niche: are likely to be found.

1 A substantial 'Weberian' framework for the public service is needed to establish overall competence and accountability before one can usefully think of introducing bureaucratic competition of any type, especially bilateral competition. To a greater extent than the 'traditional' model of a single, monopolistic public implementing agency obtaining funds solely from one Ministry, the effective regulation of bureaucratic competition requires the timely collection, analysis and presentation of considerable amounts of reliable information. And this in turn requires that different public agencies should be sufficiently independent of one another that they do not simply engage in collusive cheating of the taxpayer. If the local office of the Highways Ministry in a Sri Lankan district takes money from both the central Ministry and the Integrated Rural Development Project office to improve village access roads, both sponsoring agencies need to be able to assess what was done with the money they provided, compare the performance of the district office with that of alternative recipients of their funds, know whom to hold accountable for the use of the money, and be motivated and empowered to take action in the case of abuse.

2 Competition is not appropriate to public organizations performing regulatory functions. Where rules are to be enforced, clarity and clear responsibility are primary concerns. Competition is relevant to both the provision of services - in the 'static efficiency' mode - and to the stimulation of new methods and techniques for tackling development problems.

3 Bilateral competition involves competition (for the services of implementing agencies) between sponsoring agencies. While intended to operate only in the formal funding and contracting arena, such competition will always tend to spill over into the more political and conflictual dimensions of relationships within bureaucracies. It may be problematic for this reason. This is especially likely where rival sponsoring agencies occupy close and similar positions in the organizational hierarchy. For this reason, bilateral competition is most likely to prove stable in politico-administrative systems which are either explicitly federal or encompass two or more levels of administration with considerable financial autonomy from one another. In the Sri Lankan case, the aid donors effectively constituted an alternative source of funding.

\footnotetext{
${ }^{23}$ The experience of the Sri Lanka IRDP has contributed to the concept of 'bypass' elaborated by, inter alia, Lars-Eric Birgegård, a Swedish rural development consultant who has worked like me, and with me, on the Sri Lanka programme. Birgegard (1987) and other commentators on IRDPs have been responding above all to the observation that, being foreign funded, IRDPs have frequently been granted an administrative status that is both distinctive and privileged in relation to 'normal' government agencies. The term
}

\footnotetext{
'bypass' - i.e. bypassing normal structures and procedures - is then used in a perjorative sense to indicate disapproval of an arrangement which is said to be 'unsustainable'. One would not wish to argue that these concerns are entirely misplaced. The point is that the effects of deviating from the normal bureaucratic framework are assessed as if they can almost by definition amount only to costs. The potential benefits of doing things differently and of having more than one model to assess are ignored.
} 


\section{REFERENCES}

Bendix, R., 1966, Max Weber; An Intellectual Portrait, Methuen, London

Birgegård, L-E., 1987, 'A review of experiences with integrated rural development (IRD)', Swedish University of Agricultural Sciences, International Rural Development Centre, RD Analysis Section, Issue Paper No 3, Uppsala

Downs, A. J., 1967, Inside Bureaucracy, Little, Brown and Co., Boston

Esman, M. J., 1991, Management Dimensions of Development. Perspectives and Strategies, Kumarian Press, West Hartford, Connecticut

Handy, C., 1990, The Age of Unreason, Arrow Books, London

Heginbotham, S. J., 1975, Cultures in Conflict: The Four Faces of Indian Bureaucracy, Columbia University Press, New York

Hood, C., 1991, ‘A public management for all seasons?', Public Administration, Vol 69 No 1

IRDP, 1987, Integrated Rural Development Project, Ratnapura, foint Forestry Mission, I987, Advisory Report, Ratnapura, Sri Lanka

Israel, I., 1987, Institutional Development. Incentives to Performance, The Johns Hopkins Press, Baltimore and London

Jackson, P. M., 1982, The Political Economy of Bureaucracy, Phillip Allan, Deddington

Jacques, E., 1991, 'In praise of hierarchy', reprinted in G. Thompson et al.

Laing, R., 1986, Health and Health Services for Plantation Workers, Evaluation and Planning Centre for Health Care, London School of Hygiene and Tropical Medicine

Laudau, M., 1969, 'Redundancy, rationality and the problem of duplication and overlap', Public Administration Review, Vol 29 No 4

Leonard, D., 1977, Reaching the Peasant Farmer: Organization Theory and Practice in Kenya, University of Chicago Press, Chicago

Lim, G. C. and Moore, R. J., 1989, 'Privatization in developing countries: ideal and reality', International fournal of Public Administration, Vol 12 No 1

Lindblom, C., 1977, Politics and Markets, Basic Books, New York
March, J. G. and Olsen, J. P., 1989, Rediscovering Institutions. The Organizational Basis of Politics, The Free Press, New York

Moe, T. M., 1984, 'The New Economics of Organization', American Journal of Political Science, Vol 28 No 4

Niskanen, W. A., 1971, Bureaucracy and Representative Government, Aldine, Chicago

-1973, Bureaucracy: Servant or Master? Lessons from America, Institute of Economic Affairs, London

Ouchi, W., 1980, 'Markets, bureaucracies and clans', Administrative Science Quarterly, Vol 25 No 1

Peters, T. J., 1987, Thriving on Chaos. Handbook for a Management Revolution, Alfred A. Knopf Inc., New York

-and R. H. Waterman, 1982, In Search of Excellence. Lessons from America's Best Run Companies, Harper and Row, London and New York

Pfeffer, J. and Salancik, G. R., 1978, The External Control of Organizations: A Resource Dependence Perspective, Harper and Row, New York

Schaffer, B., 1980, 'Insiders and outsiders: insidedness, incorporation and bureaucratic politics', Development and Change, Vol 11 No 2

Selznick, P., 1943, 'An approach to a theory of bureaucracy', American Sociological Review, Vol 8: 47-54

Streek, W. and Schmitter, P. C., 1985, 'Community, market, state - and associations? The prospective contribution of interest governance to social order', in W. Streek and P. C. Schmitter (eds.), Private Interest Government; Beyond Market and State, Sage, London

Thompson, G. et al. (eds.), 1991, Markets, Hierarchies and Networks; The Coordination of Social Life, Sage, London

Tullock, G., 1965, The Politics of Bureaucracy, Public Affairs Press, Washington, DC. (Originally published in 1965; references here to the 1987 reprint by University Press of America, Langham, MD, New York and London)

Von Mises, L., 1944, Bureaucracy, Yale University Press, New Haven

Weber, M., 1922, 'The development of bureaucracy and its relation to law', (from Wirtschaft und Gesellschaft), W. G. Runciman (ed.), Weber. Selections in Translation, Cambridge University Press, 1978

Wildavsky, A., 1979, The Art and Craft of Policy Analysis, Macmillan, London 